Arq. Bras. Med. Vet. Zootec., v.56, n.2, p.270-274, 2004

\title{
Communication
}

[Comunicação]

\section{Clinical and pathological study of feline mammary fibroadenomatous change associated with depot medroxyprogesterone acetate therapy}

\author{
[Aspectos clínicos e patológicos da alteração fibroadenomatosa mamária felina associada à terapia com acetato de \\ medroxiprogesterona repositório] \\ A.P. Loretti $^{1 *}$, M.R.S. Ilha $^{2}$, I. Breitsameter ${ }^{3}$, C.S. Faraco ${ }^{3}$ \\ ${ }^{1}$ Faculdade de Medicina Veterinária - Universidade Federal do Rio Grande do Sul \\ Caixa Postal 15094 \\ 91540-000 - Porto Alegre, RS \\ ${ }^{2}$ Médica Veterinária, Mestre em Patologia Veterinária \\ ${ }^{3}$ Hospital de Clínicas Veterinárias - Universidade Federal do Rio Grande do Sul
}

Feline mammary fibroadenomatous change (FMFAC) is a growth disturbance in which the mammary glands become exceedingly enlarged due to rapid but seemingly orderly, nonneoplastic expansion of ductal epithelium and stroma (Allen, 1973). It is seen mainly in young, sexually intact female cats at puberty during the first estral cycle, pregnancy or pseudo-gestation. It represents a hormone-dependent lesion in which endogenous progesterone induces an exaggerated proliferative response of the mammary glandular tissue leading to massive enlargement of the mammary glands (Hayden, Johnson, 1986). Progestin-induced local synthesis of $\mathrm{GH}$ and insulin-like growth factors (IGFs) in mammary epithelial cells as well as estrogen priming of the mammary tissue by progesterone have been suggested as additional pathogenetic mechanisms involved in the development of FMFAC (Mol et al., 1996). FMFAC has also been associated with synthetic progestin therapy e.g. medroxyprogesterone acetate (MPA) and megestrol acetate (MA) when used during prolonged periods (months to years) in intact or neutered female and male adult cats (Hayden et al., 1989). MPA is commercially available as a repositol (depot) injectable product used mainly as a contraceptive drug for dogs and

Recebido para publicação em 17 de outubro de 2002

Recebido para publicação, após modificações, em 29 de setembro de 2003

*Endereço para correspondência: Rua Paissandu, 385/201, Bairro Flamengo, 22210-080 - Rio de Janeiro, RJ,

E-mail: aloretti@hotmail.com cats. A single injection of depot MPA forms a compound that is capable of maintaining effective circulating concentrations for several months (Plumb, 1999). In some countries, there are no licensed products to prevent or suppress the estrus in female cats (Noakes et al., 2001). Nevertheless, in other countries, parenterally administered steroids are still available in the market for these purposes (Concannon, MeyersWallen, 1991). In Brazil, therapy with MPA continues to be used in feline veterinary clinical practice despite its deleterious effects. Clusters of cases of FMFAC have been described in this country in recent years. There have been an increasing number of anecdotal and unpublished reports as well as short communications and retrospective studies from Brazilian local university veterinary hospitals and private practitioners which describe cases of young cats treated with one single dosis of MPA that developed FMFAC (Trindade et al., 2001; Souza et al., 2002). A cause and effect relationship between MPA administration and FMFAC is still a current focus of considerable debate and remains as a controversial issue due to the confounding effects of synthetic progestins and those of endogenous hormones on mammary tissues.

The purpose of the present study is to report the signalment, history, clinical and pathological findings, management and outcome of six cases of FMFAC associated with MPA therapy. 
From 1999 to 2001, six cases of FMFAC affecting sexually intact crossbred female cats aged between six and 12 months were referred to two Brazilian university veterinary hospitals that have together an annual caseload of approximately 900 cats. Information regarding signalment, history, clinical findings, therapy and management were retrieved from referring veterinarians and owners.

All the animals with FMFAC received one single subcutaneous (sc) injection of depot injectable MPA within the recommended dosage $(0,5-1 \mathrm{ml})$ for prevention of estrus. In one animal, the injection of MPA was given when the animal was showing behavioral signs typical of estrusproestrus and two animals were pregnant when MPA was dosed. In those two cases, pregnancy was diagnosed only during therapeutic neutering. Initial onset of FMFAC after MPA dosing varied from two days to three months.

The clinical picture consisted of enlargement of the mammary glands of variable severity in which only the axilary mammary glands or all the mammary glands were affected at the same time. Some cats developed sudden, rapid and alarming expansive growth of the mammary glands. In other animals, mammary enlargement was slow and progressive. Growth rate of the mammary lesions ranged from two days to one month. The mammary growths were sharply circumscribed and had clearly delineated borders (Fig. 1). In some cases, mammary glands were similarly enlarged whereas in other cases mammary gland enlargement varied considerably. Each hyperplastic mammary gland measured up to $6 \mathrm{~cm}$ in diameter. They were soft and fluctuant or firm. In some cases, the overlying skin was tense and erythematous or dark and necrotic. In those cases, the enlarged mammary glands had an alopecic, moist, ulcerated, bleeding or exsudative surface. Inflammatory and necrotic lesions were more severe in the axillary and inguinal glands. Apart from the aforementioned mammary lesions, no other clinical signs were observed except for two animals which showed signs of systemic illness including depression, fever and mucosal membrane pallor (anemia). Therapeutic surgical procedures for FMFAC included neutering, mastectomy or both.

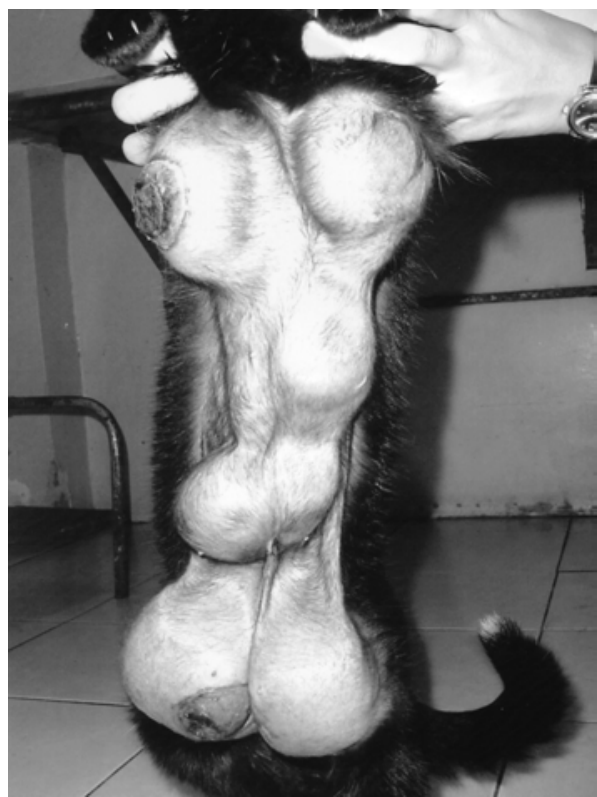

Figure 1. Feline mammary fibroadenomatous change in an eight-month-old pregnant queen that received one single injection of medroxyprogesterone acetate and developed the condition 15 days after dosing (case 6). Marked assymetrical and bilateral enlargement of the mammary chains. Ulcerated lesions on the right axillary and inguinal mammary glands.

Broad spectrum antibiotics and topic antiinflammatory and analgesic gels were prescribed for those animals with extensive ulcerative lesions on the skin. One anemic animal required blood transfusion. One animal died spontaneously and one other was humanely euthanized. Grossly, the external surface of the hyperplastic mammary glands was homogeneous or multilobulated and encapsulated. The enlarged glands adhered tightly to the covering skin. The cut surface was diffusely white, white-yellow or pink, shiny and homogeneous. Alternatively, the sectioned surface revealed extensive areas of red or dark-red discoloration that corresponded to foci of necrosis which were well-circunscribed and could be seen through the darkened, devitalized skin. No other significant gross lesions were observed in other organs. Both pregnant cats had two fetuses in each of the uterine horns. Gestation was estimated to have 28-35 days in length based on the size of the fetuses. 
In four out of six cases, samples of the affected mammary glands were sent for histological evaluation. In two animals, the disease was diagnosed based only on the history and clinical picture. Histologically, there was diffuse fibroepithelial hyperplasia characterized by varying degrees of proliferation of both intralobular mammary ductal epithelium and interlobular stroma. A summary of the clinical and pathological findings, therapy and clinical outcome is given in Table 1.

Table 1. Clinical and pathological findings, therapy and clinical outcome for six cats with feline mammary fibroadenomatous change

\begin{tabular}{ccccc}
\hline Case & Age & History and clinical signs & Therapy & Follow-up \\
\hline & $\begin{array}{c}\text { Symmetrical, bilateral enlargement } \\
\text { of both mammary chains; } \\
1 \text { SC injection of MPA } \\
\text { at 9mo of age }\end{array}$ & OV & $\begin{array}{c}\text { Continuous expansive growth } \\
\text { and marked enlargement of } \\
\text { all mammary glands after OV; }\end{array}$ \\
& $10 \mathrm{mo}$ & & died spontaneously 3d after neutering
\end{tabular}

\begin{tabular}{|c|c|c|c|c|}
\hline 2 & $9 \mathrm{mo}$ & $\begin{array}{l}\text { Asymmetrical enlargement of the } \\
\text { axilary mammary glands during 2-3d; } \\
1 \text { SC injection MPA at } 6 \text { mo of age }\end{array}$ & $\begin{array}{l}\text { OV } \\
\text { MT RM }\end{array}$ & $\begin{array}{l}\text { Continuous expansive growth and } \\
\text { marked enlargement of } \mathrm{LM}_{1} \text { after OV/MT RM } \\
\text { complete regression } 2 \mathrm{mo} \text { after OV/MT RM } \\
\text { no recurrence } 24 \mathrm{mo} \text { neutering }\end{array}$ \\
\hline 3 & $\pm 1 \mathrm{yr}$ & $\begin{array}{l}1 \mathrm{SC} \text { injection MPA after the } 1^{\text {st }} \text { estrus; } \\
\text { symmetrical and bilateral enlargement of } \\
\text { both mammary chains } 15 \mathrm{~d} \text { after dosing }\end{array}$ & $\begin{array}{l}\mathrm{OV} \\
\mathrm{MT} \mathrm{RM}_{1}\end{array}$ & $\begin{array}{l}\text { Partial regression } 1 \mathrm{mo} \text { after OV/MT; } \\
\text { recurrence } 2 \mathrm{mo} \text { after OV/MT; } \\
\text { euthanasia was carried out }\end{array}$ \\
\hline 4 & $1 \mathrm{yr}$ & $\begin{array}{l}\text { Asymmetrical, bilateral enlargement } \\
\text { of both mammary chains; } \\
1 \text { contraceptive SC injection; } \\
\text { pregnancy ( } 2 \text { fetuses) }\end{array}$ & $\mathrm{OVH}$ & Died spontaneously $3 \mathrm{~d}$ after $\mathrm{OVH}$ \\
\hline 5 & $6 \mathrm{mo}$ & $\begin{array}{c}1 \mathrm{SC} \text { injection of MPA; } \\
\text { asymmetrical, bilateral enlargement of } \\
\text { both mammary chains } 2-3 \mathrm{~d} \text { after dosing; } \\
\text { expansive growth continued during the } \\
\text { following } 30 \mathrm{~d}\end{array}$ & $\begin{array}{c}\mathrm{MT} \\
\mathrm{RM}_{1}-\mathrm{RM}_{4}\end{array}$ & $\begin{array}{c}\text { Complete regression and } \\
\text { no recurrence } 24 \mathrm{mo} \text { after MT }\end{array}$ \\
\hline 6 & $8 \mathrm{mo}$ & $\begin{array}{l}\text { Asymmetrical, bilateral enlargement of } \\
\text { both mammary chains } 15 \mathrm{~d} \text { after } \\
\text { contraceptive SC injection; } \\
\text { pregnancy (28-35d) (2 fetuses) }\end{array}$ & $\mathrm{OVH}$ & $\begin{array}{l}\text { Continuous expansive growth and } \\
\text { marked enlargementof mammary glands, } \\
\text { ulceration of the overlying skin during } \\
\text { the following month after OVH; } \\
\text { complete regression } 6 \text { mo after OVH }\end{array}$ \\
\hline
\end{tabular}

In the present report, it is suggested that most if not all of the female cats developed FMFAC when given one single injection of depot MPA. Thus, the disorder could be attributed to the potent and long-term effects of the repositol injectable forms of synthetic progestins since contraceptive recommended doses and injection frequencies were not exceeded. The adverse effects of single depot MPA injections could also be associated with dosing during estrus-proestrus when circulating estrogen concentrations are on the rise or during pregnancy when progesterone levels are high. FMFAC associated with one single injection of synthetic progestins has been reported only on rare occasions. Normally, repeated doses of synthetic progestins during months to years are required to produce FMFAC in older animals. When it happens, only one or two glands are affected, not the entire mammary chains as seen in this report (Hayden, Johnson, 1986).

In the present study, spontaneous resolution of FMFAC without recurrence of the condition ocurred in one female cat. Similar cases have been described only ocasionally (Hayden, Johnson 1986). The pathogenetic mechanisms involved in those atypical situations remain to be 
determined. Another unusual clinical outcome observed in this report was of one cat which presented partial reduction of the mammary hyperplastic changes after ovariectomy followed by recrudescence of the lesions. Recurrence of this condition after neutering has been reported on rare occasions (Martin de las Mulas et al., 2000) but it is not to be expected unless exogenous progestagen is administered after spaying (Carpenter et al., 1987). The atypical presentation of this disorder could be attributed to the long-lasting effect of depot synthetic progestins. Alternatively, additional yet unknown sources of sexual steroids or other physiological mechanisms including progestininduced mammary $\mathrm{GH}$ local synthesis and estrogen priming of the mammary tissue to progesterone or both could possibly be involved in this unusual event.

Rapid, massive mammary enlargement is a dramatic and severe local anabolic and general catabolic event observed in FMFAC. Complications, both of the condition itself and of spaying while mammary enlargement is present, are common and may be fatal (Carpenter et al., 1987). In this study, it is suggested that a number of factors could be involved in the poor clinical outcome of some cases of FMFAC. It is assumed that the necrotic skin overlying the mammary glands displayed a portal of entry for secondary bacterial infection and mastitis and septicemia ensued. Extremely rapid growth displayed by the mammary glands resulted in necrosis owing to inadequacy of blood supply. Necrosis, ulceration and inflammation of the enlarged glands associated with systemic infection, cutaneous venous thrombi leading to embolism and pulmonary arterial thrombosis have been described in those cases of guarded prognosis which culminate in the death of the animals (Carpenter et al., 1987). Intramammary and cutaneous massive hemorrhage, congestion and ulceration resulting in substantial blood loss and anemia could also have contributed to the poor clinical outcome of one of those cats.

In this report, it is suggested that MPA played the major role inducing FMFAC. In those cases, the noxious effects of MPA were probably enhanced by other endogenous hormones e.g. estrogen, endogenous progesterone, mammary $\mathrm{GH}$, IGFs and adrenocortical sexual steroids. However, this hypothesis cannot be properly tested since mammary tissue samples were not examined for PR, ER, GH and IGFs and no hormone serum determinations were done.

Keywords: cat, feline mammary fibroadenomatous change, progesterone

\section{RESUMO}

Descrevem-se seis casos de alteração fibroadenomatosa mamária felina (AFAMF) associada à administração de uma única injeção de acetato de medroxiprogesterona (AMP) na dose recomendada pelos fabricantes. A doença foi observada em gatas jovens não-castradas atendidas em dois hospitais veterinários de 1999 a 2001. O diagnóstico de AFAMF foi feito com base no histórico, sinais clínicos e achados macroscópicos e confirmado histologicamente em quatro dos seis casos. Sugere-se que a ocorrência da AFAMF esteja associada ao efeito prolongado de uma única injeção de AMP de depósito administrada em situações nas quais o emprego dessa terapia não é recomendado.

Palavras-chave: gato, alteração fibroadenomatosa mamária felina, progesterona

\section{ACKNOWLEDGEMENTS}

The authors would like to thank the following referring veterinarians and owners who contributed to the present study: Prof. Flávio Araújo and Prof. Luís Fernando Cunha da Silva (UFPel, Pelotas, RS), Ms. Maria de Jesus Nunes
(Pelotas, RS), Dr. Ângela Franzen, Dr. Cristine Mitri, Dr. Juliana Klein Rutkoski and Dr.Lizandra Frank Carvalho, Dr. David Driemeier (UFGRS, Porto Alegre, RS) and Mr. Jessé Mello and Ms. Carmen Sangalli Mello (Viamão, RS). 


\section{REFERENCES}

ALLEN, H.L. Feline mammary hypertrophy. Vet. Pathol., v.10, p.501-508, 1973.

CARPENTER, J.L.; ANDREWS, L.K.; HOLZWORTH, J. Tumors and tumor-like lesions. In: Diseases of the cat: medicine \& surgery. Philadelphia: W.B. Saunders, 1987. p.406-596

CONCANNON, P.W.; MEYERS-WALLEN, V.N. Current and proposed methods for contraception and termination of pregnancy in dogs and cats. J. Am. Vet. Med. Assoc., v.198, p.1214-1225, 1991.

HAYDEN, D.W.; BARNES, D.M.; JOHNSON, K.H. Morphologic changes in the mammary gland of megestrol acetate-treated and untreated cats: a retrospective study. Vet. Pathol., v.26, p.104-113, 1989.

HAYDEN, D.W.; JOHNSON K.H. Feline mammary hypertrophy-fibroadenoma complex. In: KIRK R.W. (Ed.). Current veterinary therapy. 9.ed. Philadelphia: W.B. Saunders, 1986. p.477-480.

MARTIN DE LAS MULAS, J.M.; MILLAN Y.; BAUTISTA, M.J. et al. Oestrogen and progesterone receptors in feline fibroadenomatous change: an immunohistochemical study. Res. Vet. Sci., v.68, p.1521,2000

MOL, J.A.; VAN GARDEREN, E.; RUTTEMAN, G.R. et al. New insights in the molecular mechanism of progestin-induced proliferation of mammary epithelium: induction of the local synthesis of growth hormone $(\mathrm{GH})$ in the mammary glands of dogs, cats and humans. J. Steroid Biochem. Mol. Biol., v.57, p.67-71. 1996.

NOAKES, D.E.; PARKINSON, T.J.; ENGLAND, G.C.W (Eds). Arthur's veterinary reproduction and obstetrics. 8.ed. London: W.B. Saunders, 2001. p.839848.

PLUMB, D.C. Veterinary drug handbook. 3.ed. Ames: Iowa State University, 1999. p.459-464.

SOUZA, T.M.; FIGHERA, R.A.; LANGHOR, I.M. et al. Hiperplasia fibroepitelial mamária em felinos: cinco casos. Ciênc. Rural, v.32, p.891-894, 2002.

TRINDADE, W.M.; JUNIOR ALVES, M.; SANTOS, P.C.G. et al. Um caso de hiperplasia fibroepilelia. In: ENCONTRO nacional de patologia veterinária. 10. São Paulo. Resumos... São Paulo: USP, 2001.p.210. 